quel B, et al. Strain identification of Mycobacterium tuberculosis by DNA fingerprinting: recommendations for a standardized methodology. J Clin Microbiol 1993;31:406-409.

9. Bauer J, Yang Z, Poulsen S, Andersen AB. Results from 5 years of nationwide DNA fingerprinting of Mycobacterium tuberculosis complex isolates in a country with a low incidence of $M$ tuberculosis infection. $J$ Clin Microbiol 1998;36:305-308.

10. Witte W, Cuny C, Braulke C, Heuck D, Klare I. Widespread dissemination of epidemic MRSA in German hospitals. Eurosurveillance 1997;2:25 28.

11. Givney R, Vickery A, Holliday A, Pegler M, Benn R. Evolution of an endemic methicillin-resistant Staphylococcus aureus population in an Australian hospital from 1967 to 1996. J Clin Microbiol 1998;36:552-556.

12. Cookson BD, Aparicio P, Deplano A, Struelens M, Goering R, Marples R. Inter-centre comparison of pulsed-field gel electrophoresis for the typing of methicillin-resistant Staphylococcus aureus. J Med Microbiol 1996;44:179-184.

13. van Belkum A, Kluytmans J, van Leeuwen W, Bax R, Quint W, Peters E, et al. Multicenter evaluation of arbitrarily primed PCR of typing of Staphylococcus aureus strains. J Clin Microbiol 1995;33:1537-1547.

14. Grundmann HJ, Towner KJ, Dijkshoorn L, Gerner-Smidt P, Maher M, Seifert H, et al. Multicenter study using standardized protocols and reagents for evaluation of reproducibility of PCR-based fingerprinting of Acinetobacter spp. J Clin Microbiol 1997;35:3071-3077.

15. DelVecchio VG, Petroziello JM, Gress MJ, McCleskey FK, Melcher GP, Crouch HK, et al. Molecular genotyping of methicillin-resistant Staphylococcus aureus via fluorophore-enhanced repetitive-sequence PCR. J Clin Microbiol 1995;33:2141-2144.

16. Deplano A, Vaneechoutte M, Verschraegen G, Struelens MJ. Typing of Staphylococcus aureus and Staphylococcus epidermidis strains by PCR analysis of inter-IS256 spacer length polymorphisms. J Clin Microbiol 1997;35:2580-2587.

17. Vos P, Hogers R, Bleeker M, Reijans M, van de Lee T, Hornes M,et al. AFLP: a new technique for DNA fingerprinting. Nucleic Acids Res 1995;23:4407-4414.

18. Mazurek GH, Reddy V, Marston BJ, Haas WH, Crawford JT. DNA fingerprinting by infrequent-restriction-site amplification. J Clin Microbiol 1996;34:2386-2390.

19. Riffard S, Lo Presti F, Vandenesch F, Forey F, Reyrolle M, Etienne J. Comparative analysis of infrequent-restriction-site PCR and pulsed-field gel electrophoresis for epidemiological typing of Legionella pneumophila serogroup 1 strains. J Clin Microbiol 1998;36:161-167.

20. Fields PI, Blom K, Hughes HJ, Helsel LO, Feng P, Swaminathan B. Molecular characterization of the gene encoding $\mathrm{H}$ antigen in Escherichia coli and development of a PCR-restriction fragment length polymor- phism test for identification of E coli O157:H7 and O157:NM. J Clin Microbiol 1997;35:1066-1070.

21. Nachamkin I, Ung H, Patton CM. Analysis of HL and O serotypes of Campylobacter strains by the flagellin gene typing system. J Clin Microbiol 1996;34:277-281.

22. Newcombe J, Dyer S, Blackwell L, Cartwright K, Palmer WH, McFadden J. PCR-single stranded conformational polymorphism analysis for non-culture-based subtyping of meningococcal strains in clinical specimens. J Clin Microbiol 1997;35:1809-1812.

23. Harrington CS, Thomson-Carter FM, Carter PE. Evidence for recombination in the flagellin locus of Campylobacter jejuni: implications for the flagellin gene typing scheme. J Clin Microbiol 1997;35:2386-2392.

24. van Belkum A, Riewerts Eriksen N, Sijmons M, van Leeuwen W, VandenBergh M, Kluytmans J, et al. Are variable repeats in the spa gene suitable targets for epidemiological studies of methicillin-resistant Staphylococcus aureus strains? Eur J Clin Microbiol Infect Dis 1996;15:768-769.

25. Hoefnagels-Schuermans A, Peetermans WE, Struelens MJ, Van Lierde $\mathrm{S}$, Van Eldere J. Clonal analysis and identification of epidemic strains of methicillin-resistant Staphylococcus aureus by antibiotyping and determination of protein A gene and coagulase gene polymorphisms. J Clin Microbiol 1997;35:2514-2520.

26. Dean D, Schachter J, Dawson CR, Stephens RS. Comparison of the major outer membrane protein variant sequence regions of $\mathrm{B} / \mathrm{Ba}$ isolates: a molecular epidemiologic approach to Chlamydia trachomatis infections. J Infect Dis 1992;166:383-392.

27. Calderwood SB, Baker MA, Carroll PA, Michel JL, Arbeit RD, Ausubel FM. Use of cleaved amplified polymorphic sequences to distinguish strains of Staphylococcus epidermidis. J Clin Microbiol 1996;34:2860-2865.

28. Perea Mejia LM, Stockbauer KE, Pan X, Cravioto A, Musser JM. Characterization of group A streptococcus strains recovered from Mexican children with pharyngitis by automated DNA sequencing of virulencerelated genes: unexpectedly large variation in the gene (sic) encoding a complement-inhibiting protein. J Clin Microbiol 1997;35:3220-3224.

29. van Leeuwen W, Sijmons M, Sluijs J, Verbrugh H, van Belkum A. On the nature and use of randomly amplified DNA from Staphylococcus aureus. J Clin Microbiol 1996;34:2770-2777.

30. Kamerbeek J, Schould L, Kolk A, van Achterveld M, van Soolingen D, Kuijper S, et al. Simultaneous detection and strain differentiation of Mycobacterium tuberculosis for diagnosis and epidemiology. J Clin Microbiol 1997;35:907-914.

31. Chee M, Yang R, Hubbell E, Berno A, Huang XC, Stern D, et al. Accessing genetic information with high-density DNA arrays. Science 1996;274:610-614.

\title{
Nosocomial Postoperative Endophthalmitis
}

\section{Gina Pugliese, RN, MS Martin S. Favero, PhD}

Aaberg and coworkers evaluated the incidence of acute-onset (within 6 weeks after surgery) postoperative endophthalmitis between January 1, 1984, and December 30, 1994, at the Anne Bates Leach Eye Hospital, University of Miami Medical Center. The overall 10-year incidence of acute-onset postoperative endophthalmitis after intraocular surgery was $0.093 \%(54 / 58,123)$. Incidences by surgical category were cataract surgery with or without intraocular lens (IOL), $0.082 \%$ $(34 / 41,654)$; pars plana vitrectomy (PPV), $0.046 \%(3 / 6,557)$; penetrating keratoplasty, $0.178 \%(5 / 2,805)$; secondary IOL place- ment, $0.366 \%$ (5/1,367); glaucoma surgeries, $0.124 \%(4 / 3,233)$; combined trabeculectomy and cataract surgery, $0.114 \%$ $(2 / 1,743)$; and combined penetrating keratoplasty and cataract surgery, $0.194 \%$ $(1 / 515)$. The median visual acuity after endophthalmitis treatment was 20/200. Median acuities by procedure were cataract surgery with or without IOL, 20/133; PPV, no light perception; penetrating keratoplasty, 20/200; secondary IOL implantation, 20/40; glaucoma surgery, 20/80; and combined trabeculectomy and cataract surgery with or without IOL, 20/150.

The incidence of endophthalmitis was higher after secondary IOL implantation than after cataract extraction $(P=.008)$. After treatment, visual acuity outcomes were worse in the patients who developed endophthalmitis after PPV than after cataract extraction, glaucoma procedures, or secondary IOL implantation (analysis of variance [ANOVA], $P<.05$ ), and were better among the patients with secondary IOL implantation than after penetrating keratoplasty or PPV $(P<.05$, ANOVA). The results of this 10-year review from a large teaching center can serve as a source of comparison for other centers and future studies.

FROM: Aaberg TM Jr, Flynn HW Jr, Schiffman J, Newton J. Nosocomial acuteonset postoperative endophthalmitis survey. A 10-year review of incidence and outcomes. Ophthalmology 1998;105:1004-1010. 